Tennakoon W.D.N.S.M., \& Lasanthika W.A.J.A.J.M., Wayamba Journal of Management 12 (1)

\title{
Evaluating E-Learning Systems Success: A Case of Sri Lanka
}

\author{
W.D.N.S.M. Tennakoon ${ }^{1}$ \& W.J.A.J.M. Lasanthika ${ }^{2}$ \\ ${ }^{1,2}$ Department of Business Management \\ Faculty of Business Studies \& Finance \\ Wayamba University of Sri Lanka \\ Kuliyapitiya \\ SRI LANKA \\ tennakoon@wyb.ac.1k ${ }^{1}$, janani@wyb.ac. $1 k^{2}$
}

\begin{abstract}
E-learning, the product of technology and education, has emerged as a powerful medium of learning particularly in the higher education sector. Significance of e-learning in educational services has led to a massive growth in the number of e-learning courses and systems offering different types of services followed by the COVID 19 pandemic. Thus, evaluation of e-learning -systems is critical to ensure successful delivery, effective use, and positive impacts on learners. Survey data of Sri Lankan university student's sample tested the research hypotheses. Quantitative assessment of determinants of PLS-SEM results confirms $81.7 \%$ explanatory power of the predictor variables in explaining the variance of E-Learning Success among which Instructor Quality, Learner Quality, Service Quality, Support System Quality and Technical System Quality found significant predictors. Implications invite revisiting the theoretical models to assess the e-learning effectiveness by incorporating multifarious factors while developing elearning system of multifractality found critical for the success of any electronically driven learning experience.
\end{abstract}

Keywords-: E-Learning, E-Learning System, E-Learning System Success, PLS-SEM

\section{INTRODUCTION}

The advancement of information technology has paved way to success in many sectors such as health, finance, transportation, and agriculture...etc. In line with that wave of e-transformation, education sector too has integrated technology to its various deliverables in order to meet the expectations of stakeholders effectively. As such, Electronic Learning (E-Learning) simply is the technological adoption of education that is been vastly practiced by many educational institutions 
nowadays. Choudhury and Pattnaik (2020) defined elearning as transfer of knowledge and skills, in a well-designed course content that has established accreditations, through an electronic media like the Internet, Web 4.0, intranet and extranets. The main stakeholders of e-learning include learners, faculty, administrative $\&$ technical staff, and employers (Choudhury \& Pattnaik, 2020). E-learning found to be having a greater effect on academic performance (Abbasi et al., 2020; Almaiah et al., 2020; Ebner et al., 2020; Maldonado et al., 2011, Radha et al., 2020). It encompasses a range of activities: from supported learning to blended learning and to pure elearning (Cruz-Jesus et al. 2016; Aboagye, 2021; Radha, 2018). Online learning systems provide benefits for stakeholders located around the world. Advantages of e-learning for learners include an increased accessibility to information, better content delivery, personalized instruction, content standardization, accountability, on-demand availability, self-pacing, interactivity, confidence, and increased convenience. Minimization of costs, enabling a consistent delivery of content, and improved tracking are among the other benefits of e-learning to the faculty (Sander, 2020; AlMaroof, 2021). E-learning reduces classroom and facilities cost, training cost, travel cost, printed materials cost, labor cost, and information overload (Sander, 2020; Choudhury \& Pattnaik, 2020; Al-Maroof, 2021). E-learning initiatives call for considerable investments in technology such as hardware costs, software licenses, learning material development, equipment maintenance, and training (Abbasi et al., 2020; Al-Maroof, 2021). Al-Maroof (2021) concluded that e-learning has huge potential and can reduce costs in comparison to a traditional class room environment after initial course development. Despite these benefits, e-learning has a higher drop-out rate than traditional delivery modes (Abbasi et al., 2020; Almaiah et al., 2020; Ebner et al., 2020; Radha et al., 2020).

Nowadays, educational technologies have quickly evolved along with the prompt development of ICTs (Al-Emran and Shaalan 2015, 2017; Salloum et al., 2017; Ali et al., 2018). The last two decades have witnessed an increase in the prevalence of the internet due to the reason that universities and other educational institutions have made investments in information systems (For instance Moodle, Blackboard, Google Class...etc.) so as to help in face-to-face as well as distant course delivery (Tarhini et al., 2013; Teo et al., 2020). Using e-learning along with networked computers facilitates transmitting the digitized knowledge from the online sources to the end-user 
devices, such as a laptop, desktop and handheld devices (Misra et al. 2014; Behera 2013; Salloumet al., 2019, Shahmoradi et al., 2018).

In par with the other parallel development, the global online learning industry is sporting massive annual growth of $19 \%$ or more per year, and it's set to be a $\$ 243$ billion industry within next two years following the COVID 19 pandemic (Sander, 2020). The United States is still at the forefront of the industry in terms of market size, but other regions such as Europe, Latin America, and Asia are also starting to become increasingly prevalent players in the industry (Sander, 2020). The demand for e-learning platforms also raised due to the COVID 19 pandemic situation in the world. The lockdowns restricted physical presences and encouraged to continue studies with e-learning platforms. Consequently, the education activities across the globe are moving with the aid of e-learning systems where the quality of elearning systems matters today more than ever.

Among the top most concerns of the e-learning are the quality of elearning deliverables. This has received a substantial level of attention by scholars resulting immense number of research outcomes those attempted to clarify different facets of elearning quality (Ali \& Ahmad,2011; Fathema, Shannon
\& Ross, 2015; Mohammadi, 2015; Mtebe \& Raphael, 2018; Sander, 2020). In a nutshell, majority of these studies have examined individual aspect of key determinants of e-learning systems success ignoring the synergistic effects of all determinants affecting the success of e-learning systems (Eom \& Ashill, 2018; Janelli, 2018). Alternatively, some has looked in to the direct relationships between e-learning quality factors and usage or satisfaction which is again not addressing the system as a whole operating unit (Janelli, 2018; Mtebe \& Raphael, 2018; Sander, 2020).

Success of e-learning systems found to be multifaceted (Sander, 2020). Hence, any assessment should primarily account both the individual effect and the combined effect of the predictors. Additionally, the level of influence reported to vary by the context itself too (Janelli, 2018; Ebner et al., 2020). On account of the fact that e-learning success factors vary in terms of their relative significance based on the context, different strategies have been adopted to deal with these factors. For example, in developing countries, obstacles are found in resources, accessibility \& infrastructure, as well as in existence of communication features, and the important role of social factors (e.g. learner and instructor) receive more attention. In 
contrast, in the context of developed countries, enhancing lifelong education, quality of information, usefulness of the systems, and ethical \& legal considerations are more pronounced (Mohammadi, 2015; Thiyagarajan \& Suguanthi, 2021). Moreover, e-learning is still in its infancy in developing countries where the successful implementation is challenged by context- specific factors unique to them. Despite the interest of many developing countries to implement e-learning (Grönlund \& Islam, 2010), many encounter obstacles in infrastructure, resources, information access (Thiyagarajan \& Suguanthi, 2021), personal characteristics, support from institution (Brinkerhoff, 2006), technology \& connectivity, instructors' design \& technology confidence (Janelli, 2018), as well as culture and policy (Mtebe \& Raphael, 2018). In addressing this issue, Alshare, Al-Dwaire \& Akour (2003) once reported that technology integration within education in developing countries is lagging due to cultural, political and economic concerns where the objective of e-learning is to provide basic education to a large number of poor students. This is very different from the objective of e-learning in developed countries, which aims to develop an effective knowledge economy and enhance lifelong education (Gulati, 2008; Hubalovsky, 2019). Regardless of these challenges, opportunities still exist to improve the effectiveness and success of elearning (Ebner et al., 2020; Thiyagarajan \& Suguanthi, 2021). Besides, the critical evaluation of the success factors of e-learning systems will aid in satisfying the expectations of all its stakeholders. As an emerging nation, Sri Lanka has a great potential to move forward with technological advancements. Investments in such pre-assessed, well-planned and goal-oriented technological systems are of greater demand than unplanned and ad-hoc investments on system development or modification. Therefore, the various aspects which determine the success of e-learning systems will be a prime concern for its further developments and meeting leaner needs. Motivated by these empirical lapses, the present study focused on evaluating the e-learning system success referring to the context of a developing country; the Sri Lanka.

Seamless evolution of technology has caused that there is no single consensual definition for elearning (Al-Fraihat et al, 2020). Lee, Hsieh, and Hsu (2011) defined e-learning as "an information system that can integrate a wide variety of instructional material (via audio, video, and text mediums) conveyed through e-mail, live chat sessions, online discussions, forums, quizzes, and assignments". Other researchers 
use the concept of e-learning to refer to the technology intervention in the learning process (e.g., Sun, Tsai, Finger, Chen \& Yeh, 2008).

Classification of studies in elearning from 2001 to 2016, by Cidral, Oliveira, DiFelice \& Aparicio (2018) shows us that the studies from 2001 have started with a focus on intention to use, adoption, usability, course contents and customization. Later, from 2007 onwards it has evolved to include user satisfaction. The focus of elearning researches from 2013 were mainly centered on the overall success of e-learning systems and on how students' characteristics affect e-learning (Cidral et al., 2018). In general, earlier studies have been concerned more about the technology itself. However, as the technology becomes increasingly reliable and accessible, recent research has focused more on students' \& instructors' attitudes and interactions, those play a vital role in e-learning success (Cheng,2011; Liaw, Huang \& Chen, 2007; Selim, 2007; AlSamarraie et al., 2018). Yet, only very few if not no studies have analyzed how the collective effect of e-learning success factors can explain the success of e-learning systems. With the widespread use of e-learning platforms, a further investigation is timely important to evaluate the success of e-learning systems accounting observed multi dimensionality of the construct.

\section{Success of e-learning systems}

As stated by Alireza, Fatemeh and Shában (2012) the emergence of modern technologies has promised to provide equal educational opportunities everywhere for everyone and also, diverse courses continuously. In fact, without considering the main components of learning, application of the most advanced and latest technology is in vain, and will have merely advertising aspect rather than educational. On the other hand, since unsuccessful effort in implementing e-learning is reflected in terms of return on investment, the success of $\mathrm{e}$ learning is one of the important issues (Govindasamy, 2002). In an e-learning system, not only the learner, but also all stakeholders are important. It is no doubt that internet and other digital technologies are able to support e-learning in an open, flexible and distributed environment. But how? Due to the differences between e-learning and traditional learning in some aspects, effective and successful conversion of traditional courses to e-learning may need a complex attempt and requires accurate planning, monitoring and control (Cantoni, Cellario, and Porta, 2004; Bhat et al.,2018; Fernando et al., 2019). In fact, continuity of global demand growth for elearning and acceptance of virtual communities needs to measure 
their effectiveness and usefulness in education (Valencia-Arias ;2019, Chopra et al., 2018).

\section{Models on success of e-learning systems}

The previous literature suggests different models relating to the success of e-learning : DeLone and McLean information systems success model; the Technology Acceptance Model (TAM); the User Satisfaction Models; and ELearning Quality Models (AlFraihat et al.,2018) and Multidimensional Conceptual Model for Evaluating E-learning System Success (Al-Fraihat et al.,2020). The present study adopts

Multidimensional

Conceptual Model for Evaluating E-learning System Success (AlFraihat et al.,2020) as the model comprised with greater explanatory power, and focus on variety of technical, human and social factors to evaluate the success of such systems. Further, the researchers recommended to extend their investigation to the universities in developing countries by testing their model. According the present study followed Multidimensional Conceptual Model for Evaluating E-learning System Success (AlFraihat et al.,2020) as depicted in figure 1 .

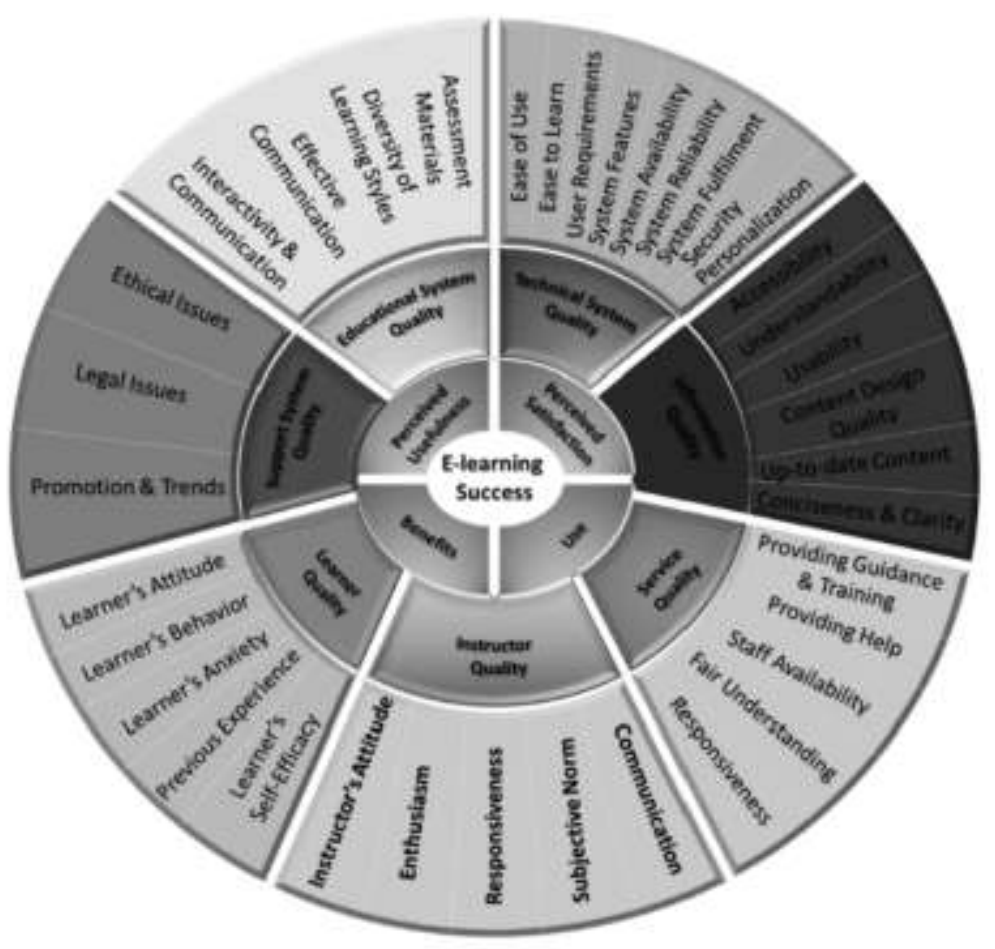

Figure 1: Multidimensional Conceptual Model for Evaluating E-learning System Success (EESS model).

Source: Al-Fraihat, D., Joy, M., and Sinclair, J. (2020) 
The ESSS model is one which includes seven independent constructs: technical system quality, information quality, service quality, educational system quality, support system quality, learner quality, and instructor quality. In addition, there are four dependent constructs: perceived satisfaction, perceived usefulness, system use, and benefits. Accordingly, the research model for the study developed as presented in figure 2.

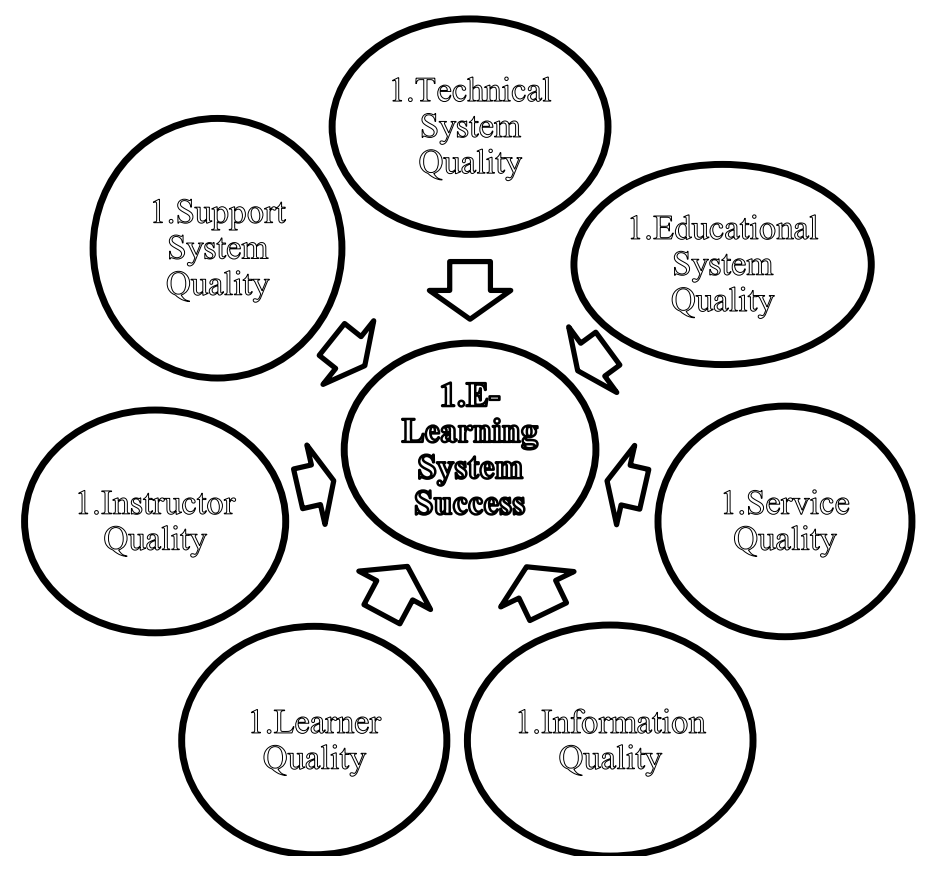

Figure 2 : Research Model

\section{Research Hypotheses}

The hypotheses developed based on the connections in the model are presented in this section.

\section{System quality (SQ)}

In the original model of Delone and McLean (2003) the researchers assumed that system quality directly affects use and user satisfaction. Several researchers applied the DeLone and McLean model in the information systems context and found a positive association between system quality and use (Halawi, McCarthy, and Aronson, 2008; Po-An Hsieh and Wang, 2007; Iivari, 2005; Tularam, 2018). In the e-learning 
systems context, system quality was also proved to be strongly related to use (Balaban, $\mathrm{Mu}$, and Divjak, 2013; Garcia-Smith and Effken, 2013; Lin, 2007; Marjanovic et al., 2016). Based on these findings, researchers therefore, assume that the higher the technical quality of the elearning system, the more satisfied the users are. Also, if users find the e-learning system compatible with their requirements, this would positively make users utilize it and consider it useful. Thus, the following hypothesis is proposed:

H1: Technical system quality positively influences success of e- learning system

\section{Information quality (IQ)}

The relationships between information quality and each of the three constructs - use, satisfaction, and usefulness have been studied empirically by e-learning researchers. For example, Klobas and McGill (2010) and c) found a significant relationship between information quality and both use and satisfaction with the Learning Management System (LMS). The relationship between information quality and perceived usefulness was found significant in the study of Chen (2010) with e-learning systems in an organizational context, and a similar result found by Lwoga (2014) with web-based LMSs. Therefore, we may assume that improved quality of information in the e- learning system will positively lead to an increase in perceived usefulness, perceived satisfaction, and system usage. Thus, we hypothesize that:

$\mathrm{H} 2$ : Information quality positively influences success of e-learning system

\section{Service quality (SQ)}

The construct has been utilized in the information systems field. For example, the relationship between SRQ and satisfaction was confirmed by Chen and Cheng (2009) in an online shopping system. The direct relationship between SRQ and use was found significant by Wang and Liao (2008) in an egovernment system. Similarly, in the context of e-learning, the relationship between SRQ and satisfaction was found significant in the Roca et al. (2006) and Ozkan and Koseler (2009) models. The relationship between SRQ and perceived usefulness proposed in the conceptual model developed by Pham (2019), Hagos, Garfield, and Anteneh (2016) and Lwoga (2014) was shown empirically to be significant in the study conducted by Al-Sabawy (2013) and Ngai, Poon, and Chan (2007). Accordingly, the following hypothesis are proposed:

H3: Service quality positively influences success of e-learning system 


\section{Educational system quality (ESQ)}

Hassanzadeh et al. (2012) found that educational system quality positively and directly influences user satisfaction and indirectly the use of the system, which indicates that educational features in the e-learning system, and facilities like discussion forums, chat-rooms, collaborative learning tools, can result in user satisfaction and maximizing their usage of the e-learning systems. Social interaction was employed as a key factor of success in computer supported collaborative learning (CSCL) and found to have a significant effect on student learning (Xing, Kim, and Goggins, 2015; Nikolić, 2018; Nikolić, 2019). The relationship between educational system quality and perceived usefulness was found significant for webbased e-learning systems in the study undertaken by Liu, Liao, and Peng (2005) and by Almaiah et al.(2016) for mobile learning systems. Kim, Trimi, Park, and Rhee (2012), Nikolić et al. and Mohammadi (2015) found a positive relationship between educational system quality and satisfaction. In addition, the relationships between diversity in assessment materials, and learner interaction in the e-learning system with perceived satisfaction, were found significant by Cidral et al. (2018). Further, the relationship between educational system features and usefulness was found significant by Liu et al. (2005) for a web- based e-learning system. The same results were obtained by Liaw and Huang (2013) where a significant relationship between the interactive learning environment construct with both perceived usefulness and perceived satisfaction was found. Therefore, the following hypothesis about educational system quality are proposed:

H4: Educational System Quality positively influences the success of e-learning system

\section{Support system quality (SUP)}

In the literature on e-learning system success, supportive issues in the e-learning system such as ethics and policies that outline rules, regulations, guidelines and prohibitions to communicate within the e-learning system, assignments' plagiarism rules, data protection, and other legal and copyright issues of the uploaded materials in the elearning system, in addition to the popularity and policy followed by the organization, all these issues influence the learners significantly (Khan, 2005). For example, in the empirical study conducted by Ozkan and Koseler (2009), the use of the LMS at Brunel University has increased significantly due to the encouragement students and academics received from the university to use the LMS in their modules. The researchers stated "the use of U-Link has increased significantly during the last three years. This is mainly because of 
the increasing popularity of elearning portals." The researchers studied the relationship between supportive system issues and satisfaction and found it significant. On the other hand, the organizational promotion of the e-learning system significantly and positively affected employees' satisfaction in the study conducted by Navimipour and Zareie (2015).

As stated by (Al-Fraihat et al, 2020), the popularity of the elearning system, and the policy followed by the organization to promote their e-learning system, play an important role in increasing the usage of the system by academics and learners. Therefore, researchers propose the following hypothesis:

H5: Support System Quality positively influences the success of e-learning system

\section{Learner quality (LER)}

This construct was successfully operated in several models developed by prior e-learning researchers. Several researchers examined a subset of the learner quality construct, for example, the learner's self-efficacy was studied by Ong, Lai, and Wang (2004) and a significant relationship with perceived usefulness was found. The same result was achieved by Park (2009). McGill and Klobas (2009) ;Rakic et al.(2020) studied the relationship between learner attitude toward LMS use and LMS utilization and found it significant. Additionally, the relationships between student involvement and both use and satisfaction were found significant in the study of Klobas and McGill (2010). Also, the relationships between selfefficacy and a learner's computer anxiety with perceived usefulness were studied by Chen and Tseng (2012). The relationship between learner and perceived satisfaction was found significant in the models of Sun et al. (2008) and Ozkan and Koseler (2009). Given the positive relations of the indicators associated with the variety of learner's characteristics, it is more likely that the quality of the learner will influence perceived usefulness and use of the system. Thus, propose the following hypothesis:

H6: Learner Quality positively influences the success of $\mathrm{e}$ learning system

\section{Instructor quality (INS)}

According to (Al-Fraihat et al, 2020) the instructor's role in the success of e-learning has received attention from researchers in the e-learning arena. To clarify, the model developed by Sun et al. (2008) researched the relationship between the instructor dimension, using two indicators (instructor response timeliness, instructor attitude toward e-learning), and satisfaction, and found it positively significant. Similar results were obtained by Cidral et al. (2018) where a positive 
relationship found between instructor attitude toward elearning and user's satisfaction. Lwoga (2014) employed instructor quality as a separate construct and confirmed a positive significant relationship between instructor quality and both perceived usefulness and user satisfaction. Also, instructor quality has been found to have a significant effect on learners' satisfaction with an e-learning system in the study conducted by Mtebe and Raphael (2018). Thereby the following hypothesis is proposed;

H7: Instructor Quality positively influences the success of $\mathrm{e}$ learning system

\section{METHODS}

Present study adopts EESS model (Al-Fraihat et al.,2020) based on its greater explanatory power and inclusion of wider range of predictive variables such as technical, human and social. An empirical study of quantitative approach tested the EESS model based on the LMS of a Sri Lankan state university; Wayamba University of Sri Lanka. Data collection led by instrumentalization of an online questionnaire among the level 03 undergraduates who are enrolled to Moodle based LMS of Wayamba University of Sri Lanka. Moodle was selected to test the model of the study because the University of Wayamba has adopted Moodle as the main e-learning system designed to support teaching and learning materials and activities, and to provide a number of interactive activities including forums, wikis, quizzes, surveys, chat and peer-to peer activities, serving most of the departments and students. In addition, Moodle is widely used in the education sector generally and in higher education specifically. The online survey assessed the success of ELS which is a Moodle based LMS. Sample size determination followed the "10-times rule method" which is a commonly used classic rule for deciding the sample size of Partial Least Square - Structural Equation Modelling (PLS-SEM). (Hair et al., 2011; Peng and Lai, 2012). There, the sample size should be greater than 10 times the maximum number of inner or outer model links pointing at any latent variable in the model (Goodhue et al., 2012). This yielded $70(7 * 10)$ sample units whistle the researchers succeed in drawing 263 valid responses via online survey of selected group. The sampling frame was a list of ELS IDs of all internal undergraduates of WUSL. Using lottery method, 5 times of minimum required sample size was drawn so as to avoid the potential problem of low responses. Resultantly, authors received 263 out of 350 (75\%) emailed questionnaires. Undergraduates, the study's unit of analysis offered an evaluation of the ELS properties based on 
system design, system delivery, and system outcome. The refined instruments (Al-Fraihat et al, 2020) based on measurement model validity and reliability indexes composed of 52 items falling in to seven exogenous variables (predictors) namely, Technical System Quality (TSQ), Information Quality (IQ), Service Quality (SQ), Educational System Quality (ESQ), Support System Quality (SSQ), Learner Quality (LQ), and Instructor Quality (IQ). The endogenous variable; E-Learning System Success (ELSS) contained of four reflective first-order constructs namely, Perceived Satisfaction (PS), Perceived Usefulness (PU), and Use (U) and Benefits (B) of ELSs. 5-point Likert scale was the measure of the responses in which the " 1 " stands for "Strongly Disagree" and 5 denotes "Strongly Agree". The questionnaire was pre-tested for its clarity and easy understanding through a pilot study and the face validity was achieved by obtaining the experts views of the same. Partial Least Square Structural Equation Model (PLS-
SEM) deemed to be well explaining the relationship of nexus of latent variables. It generates less contradictory results compared to regression analysis and facilitates analyzing the relationships of multiple independent and dependent variables. Further, PLS-SEM is good at increasing the parsimonious of the analysis (Hair, et al., 2011; Hair, et al., 2014; Ringle, et al., 2012; Wong, 2013). Hierarchical Component Model (HCM) of the collected data was developed using Smart PLS version 3.

\section{RESULTS}

The endogenous variable, ELearning System Success composed of four first order measures of which the measurement model was first analyzed for its reliability and validity (Hair, Sarstedt, Ringle, and Mena, 2012). Factor loadings of all the items leading to four constructs satisfy the threshold value 0.7 at the $95 \%$ confidence level (Table 1).

Table 1: Properties of First -Order Measurement Model

\begin{tabular}{|c|c|c|c|c|c|c|}
\hline Construct/Item & Loading & $\begin{array}{c}\mathrm{t}- \\
\text { Statistics }\end{array}$ & $\mathbf{C R}$ & AVE & rho_A & $\begin{array}{c}\text { Cronbach } \\
\text { Alpha }\end{array}$ \\
\hline \multicolumn{7}{|c|}{ E-Learning System Success-----------Perceived Satisfaction } \\
\hline PS42 & 0.928 & 68.365 & \multirow{4}{*}{$\begin{array}{c}0.96 \\
1\end{array}$} & \multirow{4}{*}{0.859} & \multirow{4}{*}{0.945} & \multirow{4}{*}{0.945} \\
\hline PS43 & 0.926 & 64.917 & & & & \\
\hline PS44 & 0.925 & 80.818 & & & & \\
\hline PS45 & 0.928 & 71.516 & & & & \\
\hline
\end{tabular}


Tennakoon W.D.N.S.M., \& Lasanthika W.A.J.A.J.M., Wayamba Journal of Management 12 (1)

\begin{tabular}{|c|c|c|c|c|c|c|}
\hline \multicolumn{7}{|c|}{ E-Learning System Success-----------Perceived Usefulness } \\
\hline PU46 & 0.899 & 47.581 & \multirow{4}{*}{0.959} & \multirow{4}{*}{0.853} & \multirow{4}{*}{0.943} & \multirow{4}{*}{0.942} \\
\hline PU47 & 0.942 & 93.512 & & & & \\
\hline PU48 & 0.931 & 70.046 & & & & \\
\hline PU49 & 0.922 & 62.565 & & & & \\
\hline \multicolumn{7}{|c|}{ E-Learning System Success-----------Use of E-Learning Systems } \\
\hline U50 & 0.864 & 46.397 & \multirow{4}{*}{0.903} & \multirow{4}{*}{0.700} & \multirow{4}{*}{0.858} & \multirow{4}{*}{0.855} \\
\hline U51 & 0.878 & 38.568 & & & & \\
\hline U52 & 0.870 & 36.736 & & & & \\
\hline U53 & 0.726 & 20.589 & & & & \\
\hline \multicolumn{7}{|c|}{ E-Learning System Success-----------Benefits of E-Learning Systems } \\
\hline B54 & 0.892 & 40.552 & \multirow{5}{*}{0.957} & \multirow{5}{*}{0.818} & \multirow{5}{*}{0.957} & \multirow{5}{*}{0.944} \\
\hline B55 & 0.917 & 52.596 & & & & \\
\hline B56 & 0.896 & 39.476 & & & & \\
\hline B57 & 0.896 & 52.528 & & & & \\
\hline B58 & 0.920 & 70.032 & & & & \\
\hline
\end{tabular}

$\mathrm{n}=263$

Survey Results (2020)

The Cronbach Alpha values of four constructs range between 0.855 and 0.945 . Henseler's rho (rho_A) values of these constructs range between 0.858 and 0.945. Further, the Composite Reliability (CR) of these constructs falls in between 0.903 and 0.961. For all measures of internal consistency, all constructs scored well above the threshold value of 0.7 as recommended by Nunally (1978). This indicates the high reliability of all four first-order constructs. Factor Loading and Average Variance Extracted (AVE) are considered standard measures of the convergent validity (Hair, et al., 2017; Byrne, 2016; Bagozzi, and Yi, 1998; Fronell, and Larcker, 1981). The AVE values of these constructs fall in between 0.700 and 0.859 . Convergent validity of the constructs considered adequate when the AVE exceed 0.5 (Bagozzi, and Yi, 1998; Fronell, and Larcker, 1981). Additionally, factor loadings of latent variables those greater than 0.708 theorized to be explaining minimum $50 \%$ or more of the indicator's variance of it (Hair, et al., 2017). Here, the factor loadings of all the indicators of the firstordermodel are between 0.726 and 0.942. Accordingly, it is evidenced that the all constructs satisfy the convergent validity criterion. Next, the firstorderconstructs are examined for their discriminant validity. For an acceptable level of discriminant validity, Fronell, and Larcker, (1981) recommended that the 
AVE of a latent variable should be higher than the squared correlations between the latent variables and all other variables (Chin, 2010; Chin, 1998b; Fronell, and Larcker,1981). Table 2 demonstrates the correlation matrix with the square roots of AVEs on the diagonal line (in Bold) which indicates an acceptable level of discriminant validity according to Fronell, and Larcker criterion (i.e. AVE criterion). Additionally, cross loadings are also used as a discriminant validity measure where it is expected for each indicator to load highest on the construct it is associated with (Henseler, et al., 2015; Voorhees, et al., 2016). Examination of loading of each indicator on its respective latent variable ensured that all are loaded highest on the latent variable for which they are assigned. Thus, all the constructs of first-order model confirmed to be holding acceptable level of discriminant validity.

Table 2 : Correlation Matrix - Discriminant Validity of First-Order Measurement Model

\begin{tabular}{|c|l|c|c|c|c|}
\hline & & $\mathbf{1}$ & $\mathbf{2}$ & $\mathbf{3}$ & $\mathbf{4}$ \\
\hline $\mathbf{1}$ & Benefits & $\mathbf{0 . 9 0 4}$ & & & \\
\hline $\mathbf{2}$ & $\begin{array}{l}\text { Perceive } \\
\text { Satisfaction }\end{array}$ & 0.844 & $\mathbf{0 . 9 2 7}$ & & \\
\hline $\mathbf{3}$ & $\begin{array}{l}\text { Perceived } \\
\text { Usefulness }\end{array}$ & 0.841 & 0.860 & $\mathbf{0 . 9 2 4}$ & \\
\hline $\mathbf{4}$ & Use & 0.393 & 0.385 & 0.388 & $\mathbf{0 . 8 3 7}$ \\
\hline
\end{tabular}

$\mathrm{n}=263$

Survey Results (2020)

The second-order model of the constructs is then assessed for ensuring the dimensional properties of it. Latent variable scores of the first-order constructs are used in establishing the second-order model of eight endogenous variables namely, E-Learning System Success (ELSS),
Technical System Quality (TSQ), Information Quality (IQ), Service Quality (SQ), Educational System Quality (ESQ), Support System Quality (SSQ), Learner Quality (LQ), and Instructor Quality (IQ). Table 3 shows the key measures of validity and reliability of the second-order constructs. 
Tennakoon W.D.N.S.M., \& Lasanthika W.A.J.A.J.M., Wayamba Journal of Management 12 (1)

Table 3 : Properties of Second -Order Measurement Model

\begin{tabular}{|c|c|c|c|c|c|c|}
\hline Construct/Item & Loading & $\begin{array}{c}\mathrm{t}- \\
\text { Statistics }\end{array}$ & $\mathbf{C R}$ & AVE & rho_A & $\begin{array}{c}\text { Cronbach } \\
\text { Alpha }\end{array}$ \\
\hline \multicolumn{7}{|c|}{ E-Learning System Success } \\
\hline $\begin{array}{c}\text { Perceived } \\
\text { Satisfaction }\end{array}$ & 0.941 & 84.318 & \multirow{4}{*}{0.913} & \multirow{4}{*}{0.732} & \multirow{4}{*}{0.930} & \multirow{4}{*}{0.866} \\
\hline $\begin{array}{l}\text { Perceived } \\
\text { Usefulness }\end{array}$ & 0.938 & 66.754 & & & & \\
\hline Use & 0.537 & 7.321 & & & & \\
\hline Benefits & 0.936 & 89.054 & & & & \\
\hline \multicolumn{7}{|c|}{ Technical System Quality } \\
\hline TSQ1 & 0.690 & 13.590 & \multirow{11}{*}{0.926} & \multirow{11}{*}{0.534} & \multirow{11}{*}{0.918} & \multirow{11}{*}{0.913} \\
\hline TSQ2 & 0.695 & 14.011 & & & & \\
\hline TSQ3 & 0.750 & 18.395 & & & & \\
\hline TSQ4 & 0.775 & 25.011 & & & & \\
\hline TSQ5 & 0.780 & 21.940 & & & & \\
\hline TSQ6 & 0.759 & 13.964 & & & & \\
\hline TSQ7 & 0.794 & 19.920 & & & & \\
\hline TSQ8 & 0.764 & 15.150 & & & & \\
\hline TSQ9 & 0.669 & 9.517 & & & & \\
\hline TSQ10 & 0.635 & 12.339 & & & & \\
\hline TSQ11 & 0.708 & 16.223 & & & & \\
\hline \multicolumn{7}{|c|}{ Support System Quality } \\
\hline SSQ28 & 0.870 & 45.035 & \multirow{4}{*}{0.931} & \multirow{4}{*}{0.773} & \multirow{4}{*}{0.902} & \multirow{4}{*}{0.902} \\
\hline SSQ29 & 0.890 & 50.280 & & & & \\
\hline SSQ30 & 0.880 & 34.025 & & & & \\
\hline SSQ31 & 0.876 & 38.114 & & & & \\
\hline \multicolumn{7}{|l|}{ Service Quality } \\
\hline SQ19 & 0.872 & 52.173 & \multirow{5}{*}{0.954} & \multirow{5}{*}{0.807} & \multirow{5}{*}{0.944} & \multirow{5}{*}{0.940} \\
\hline SQ20 & 0.911 & 49.664 & & & & \\
\hline SQ21 & 0.899 & 64.376 & & & & \\
\hline SQ22 & 0.920 & 72.182 & & & & \\
\hline SQ23 & 0.891 & 47.286 & & & & \\
\hline \multicolumn{7}{|l|}{ Learner Quality } \\
\hline LQ32 & 0.906 & 65.799 & \multirow{5}{*}{0.936} & \multirow{5}{*}{0.748} & \multirow{5}{*}{0.923} & \multirow{5}{*}{0.915} \\
\hline LQ33 & 0.919 & 86.315 & & & & \\
\hline LQ34 & 0.822 & 27.274 & & & & \\
\hline LQ35 & 0.776 & 20.632 & & & & \\
\hline LQ36 & 0.891 & 47.911 & & & & \\
\hline
\end{tabular}


Tennakoon W.D.N.S.M., \& Lasanthika W.A.J.A.J.M., Wayamba Journal of Management 12 (1)

\begin{tabular}{|c|c|c|c|c|c|c|}
\hline \multicolumn{7}{|c|}{ Instructor Quality } \\
\hline IQ37 & 0.870 & 31.836 & \multirow{5}{*}{0.956} & \multirow{5}{*}{0.813} & \multirow{5}{*}{0.943} & \multirow{5}{*}{0.942} \\
\hline IQ38 & 0.891 & 44.018 & & & & \\
\hline IQ39 & 0.912 & 55.219 & & & & \\
\hline IQ40 & 0.928 & 78.441 & & & & \\
\hline IQ41 & 0.906 & 50.811 & & & & \\
\hline \multicolumn{7}{|c|}{ Information Quality } \\
\hline INQ12 & 0.764 & 17.239 & \multirow{7}{*}{0.905} & \multirow{7}{*}{0.577} & \multirow{7}{*}{0.884} & \multirow{7}{*}{0.878} \\
\hline INQ13 & 0.755 & 19.341 & & & & \\
\hline INQ14 & 0.820 & 26.509 & & & & \\
\hline INQ15 & 0.766 & 19.246 & & & & \\
\hline INQ16 & 0.779 & 16.548 & & & & \\
\hline INQ17 & 0.726 & 11.721 & & & & \\
\hline INQ18 & 0.700 & 12.334 & & & & \\
\hline \multicolumn{7}{|c|}{ Education System Quality } \\
\hline ESQ24 & 0.877 & 46.685 & \multirow{4}{*}{0.939} & \multirow{4}{*}{0.794} & \multirow{4}{*}{0.914} & \multirow{4}{*}{0.914} \\
\hline ESQ25 & 0.875 & 48.333 & & & & \\
\hline ESQ26 & 0.927 & 88.279 & & & & \\
\hline ESQ27 & 0.885 & 38.419 & & & & \\
\hline
\end{tabular}

As the way first-order constructs were assessed for their validity and reliability, the constructs of second-order model were also evaluated for their dimensional properties. The Cronbach Alpha values of all latent variables range between 0.866 and 0.942 . Henseler's rho values of these constructs range between 0.884 and 0.944. Further, the Composite Reliability of these constructs falls in between 0.905 and 0.956. For all measures of internal consistency, all constructs scored well above the threshold value of 0.7 as recommended by Nunally (1978). This indicates the high reliability of all second-order constructs.
Factor Loading and Average Variance Extracted (AVE) are considered standard measures of the convergent validity (Hair, et al., 2017; Byrne, 2016; Bagozzi, and Yi, 1998; Fronell, and Larcker, 1981). The AVE values of these constructs fall in between 0.534 and 0.813 . Convergent validity of the constructs considered adequate when the AVE exceed 0.5 (Bagozzi, and Yi, 1998; Fronell, and Larcker, 1981). Additionally, factor loadings of latent variables those greater than 0.708 theorized to be explaining minimum $50 \%$ or more of the indicator's variance of it (Hair, et al., 2017). Here, the factor loadings of all 
the indicators except $\mathrm{U}, \mathrm{TSQ} 1$, TSQ10, TSQ2, and TSQ9 of the second-order model were between 0.700 and 0.941 . Yet, $\mathrm{U}$, TSQ1, TSQ10, TSQ2, and TSQ9 respectively loaded $0.537,0.690$, $0.635,0.695$, and 0.669 on their corresponding latent constructs. Based on Byrne's (2016) recommendation for factor loadings equal to or greater than 0.5 , indicator $\mathrm{U}$ is accepted since the AVE value of the construct is greater than 0.5 (0.732). Further, the factor loadings equal to or greater than 0.6 can also be accepted, provided that the corresponding AVE value is greater than 0.5 (Byrne, 2016). The contributing AVE value of TSQ latent construct is 0.534 . Accordingly, it is evidenced that the all constructs satisfy the convergent validity criterion. Next, the second-order constructs are examined for their discriminant validity. For an acceptable level of discriminant validity, Fronell, and Larcker,
(1981) recommended that the AVE of a latent variable should be higher than the squared correlations between the latent variables and all other variables (Chin, 2010; Chin, 1998b; Fronell, and Larcker,1981). Table 4 demonstrates the correlation matrix with the square roots of AVEs on the diagonal line (in Bold) which indicates an acceptable level of discriminant validity according to Fronell, and Larcker criterion. Additionally, cross loadings are also used as a discriminant validity measure where it is expected for each indicator to load highest on the construct it is associated with (Henseler, et al., 2015; Voorhees, et al., 2016). Examination of loading of each indicator on its respective latent variable ensured that all are loaded highest on the latent variable for which they are assigned. Thus, all the constructs of second-order model confirmed to be holding acceptable level of discriminant validity.

Table 4 : Correlation Matrix - Discriminant Validity of Second-Order Measurement Model

\begin{tabular}{|l|l|c|c|c|c|c|c|c|c|}
\hline & & $\mathbf{1}$ & $\mathbf{2}$ & $\mathbf{3}$ & $\mathbf{4}$ & $\mathbf{5}$ & $\mathbf{6}$ & $\mathbf{7}$ & $\mathbf{8}$ \\
\hline $\mathbf{1}$ & $\begin{array}{l}\text { E-Learning } \\
\text { System } \\
\text { Success }\end{array}$ & $\mathbf{0 . 8 5 6}$ & & & & & & & \\
\hline $\mathbf{2}$ & $\begin{array}{l}\text { Education } \\
\text { System } \\
\text { Quality }\end{array}$ & 0.749 & $\mathbf{0 . 8 9 1}$ & & & & & & \\
\hline $\mathbf{3}$ & $\begin{array}{l}\text { Information } \\
\text { Quality }\end{array}$ & 0.318 & 0.223 & $\mathbf{0 . 7 5 9}$ & & & & & \\
\hline $\mathbf{4}$ & $\begin{array}{l}\text { Instructor } \\
\text { Quality }\end{array}$ & 0.844 & 0.727 & 0.252 & $\mathbf{0 . 9 0 2}$ & & & & \\
\hline $\mathbf{5}$ & Learner & 0.837 & 0.765 & 0.282 & 0.825 & $\mathbf{0 . 8 6 5}$ & & & \\
\hline
\end{tabular}


Tennakoon W.D.N.S.M., \& Lasanthika W.A.J.A.J.M., Wayamba Journal of Management 12 (1)

\begin{tabular}{|l|l|l|l|l|l|l|l|l|l|}
\hline & Quality & & & & & & & & \\
\hline $\mathbf{6}$ & $\begin{array}{l}\text { Service } \\
\text { Quality }\end{array}$ & 0.723 & 0.689 & 0.136 & 0.723 & 0.689 & $\mathbf{0 . 8 9 9}$ & & \\
\hline $\mathbf{7}$ & $\begin{array}{l}\text { Support } \\
\text { System } \\
\text { Quality }\end{array}$ & 0.809 & 0.741 & 0.258 & 0.794 & 0.771 & 0.727 & $\mathbf{0 . 8 7 9}$ & \\
\hline $\mathbf{8}$ & $\begin{array}{l}\text { Technical } \\
\text { System } \\
\text { Quality }\end{array}$ & 0.319 & 0.2 & 0.726 & 0.202 & 0.272 & 0.12 & 0.189 & $\mathbf{0 . 7 3 1}$ \\
\hline
\end{tabular}

$\mathrm{n}=263$

Survey Results (2020)

Once the properties of the measurement model are assessed for the reliability and validity, structural model is estimated to assess the effect size of the exogeneous variable on the endogenous variable. Assessment of structural model usually involves assessing the path coefficients, assessing the collinearity, estimating the coefficient of determination, decide on effect size and test for predictive relevance of the model
(Hair, Hult, Ringle, and Sarstedt, 2014). Significance of path coefficient can be assessed using $P$ value and $t$-value of the path. As such, path coefficients of those the $P$ value is less than 0.05 (for $95 \%$ confidence level) and $\mathrm{t}$ value greater than 1.96 (for 2 tailed test) are considered significant (Hair, et al., 2017). Bootstrapping of second-order model results that some paths are statistically significant while some doesn't (Table 5).

Table 5 : Path Coefficients of Structural Model

\begin{tabular}{|c|c|c|c|c|c|}
\hline & $\begin{array}{c}\text { Original } \\
\text { Sample }(O)\end{array}$ & $\begin{array}{c}\text { Sample Mean } \\
\text { (M) }\end{array}$ & $\begin{array}{l}\text { Standard } \\
\text { Deviation } \\
\text { (STDEV) }\end{array}$ & $\begin{array}{c}\text { T } \\
\text { Statistics } \\
(\mid \mathrm{O} / \mathrm{STDE} \\
\mathrm{V} \mid)\end{array}$ & $\begin{array}{c}\mathbf{P} \\
\text { Values }\end{array}$ \\
\hline \multicolumn{6}{|c|}{ Education System Quality -> E-Learning System Success } \\
\hline & 0.075 & 0.083 & 0.065 & 1.154 & 0.249 \\
\hline \multicolumn{6}{|c|}{ Information Quality -> E-Learning System Success } \\
\hline & -0.01 & -0.008 & 0.042 & 0.233 & 0.816 \\
\hline \multicolumn{6}{|c|}{ Instructor Quality -> E-Learning System Success } \\
\hline & 0.314 & 0.305 & 0.097 & 3.248 & $0.001 * *$ \\
\hline \multicolumn{6}{|c|}{ Learner Quality -> E-Learning System Success } \\
\hline & 0.258 & 0.266 & 0.095 & 2.704 & $0.007 * *$ \\
\hline
\end{tabular}


Tennakoon W.D.N.S.M., \& Lasanthika W.A.J.A.J.M., Wayamba Journal of Management 12 (1)

\begin{tabular}{|c|c|c|c|c|c|}
\hline \multicolumn{6}{|c|}{ Service Quality -> E-Learning System Success } \\
\hline & 0.099 & 0.094 & 0.045 & 2.216 & $0.027 *$ \\
\hline \multicolumn{6}{|c|}{ Support System Quality -> E-Learning System Success } \\
\hline & 0.211 & 0.207 & 0.066 & 3.216 & $0.001 * *$ \\
\hline \multicolumn{6}{|c|}{ Technical System Quality -> E-Learning System Success } \\
\hline & 0.125 & 0.126 & 0.045 & 2.791 & $0.005 * *$ \\
\hline
\end{tabular}

Survey Results (2020)

Except Education System Quality -> E-Learning System Success path $(P=0.249, t$ value $=1.154)$ and Information Quality -> ELearning System Success path $(P$ $=0.816, t$ value $=0,233)$ all other paths possess significant path coefficients, where $P<0.05$ and $t$ value $>1.96$ (Hair, et al., 2017). The significant paths should be next assessed for their multicollinearity model (Hair, Hult, Ringle, and Sarstedt, 2014). Variance Inflation Factor of PLS algorithm is used in deciding on the possible multicollinearity issues. As to Hair, et al., (2017) no multicollinearity will be presented if the VIF values are less than 5.0 (Hair, et al., 2017). VIF values of all the inner model constructs are well below the threshold value $(<5.0)$. Hence, it is confirmed that the structural model constructs are free of multicollinearity problems (Table $6)$.

Table 6 : VIF Values of Structural Model

\begin{tabular}{|l|c|}
\hline \multicolumn{1}{|c|}{ Construct } & VIF \\
\hline Education System Quality & 2.959 \\
\hline Information Quality & 2.208 \\
\hline Instructor Quality & 4.144 \\
\hline Learner Quality & 4.139 \\
\hline Service Quality & 2.609 \\
\hline Support System Quality & 3.612 \\
\hline Technical System Quality & 2.171 \\
\hline
\end{tabular}

$\mathrm{n}=263$,

Survey Results (2020) 
Now the path significance is assessed and the absence ofmulticollinearity is ensured. Next coefficient of determination $\left(\mathrm{R}^{2}\right)$ is examined to weight the explained variance. PLS algorithm of second-order model resulted in 0.817 of $\mathrm{R}^{2}$ value. Based on independent variables' ability to account $81.7 \%$ variance of the dependent variable, it is concluded that there is a substantial level of influence by the E-Learning system qualities on the Success of E-Learning System (Hair, et al., 2017; Chin, 1998; Cohen, 1988). The above $\mathrm{R}^{2}$ value is depicted in the structural model of figure 3 .

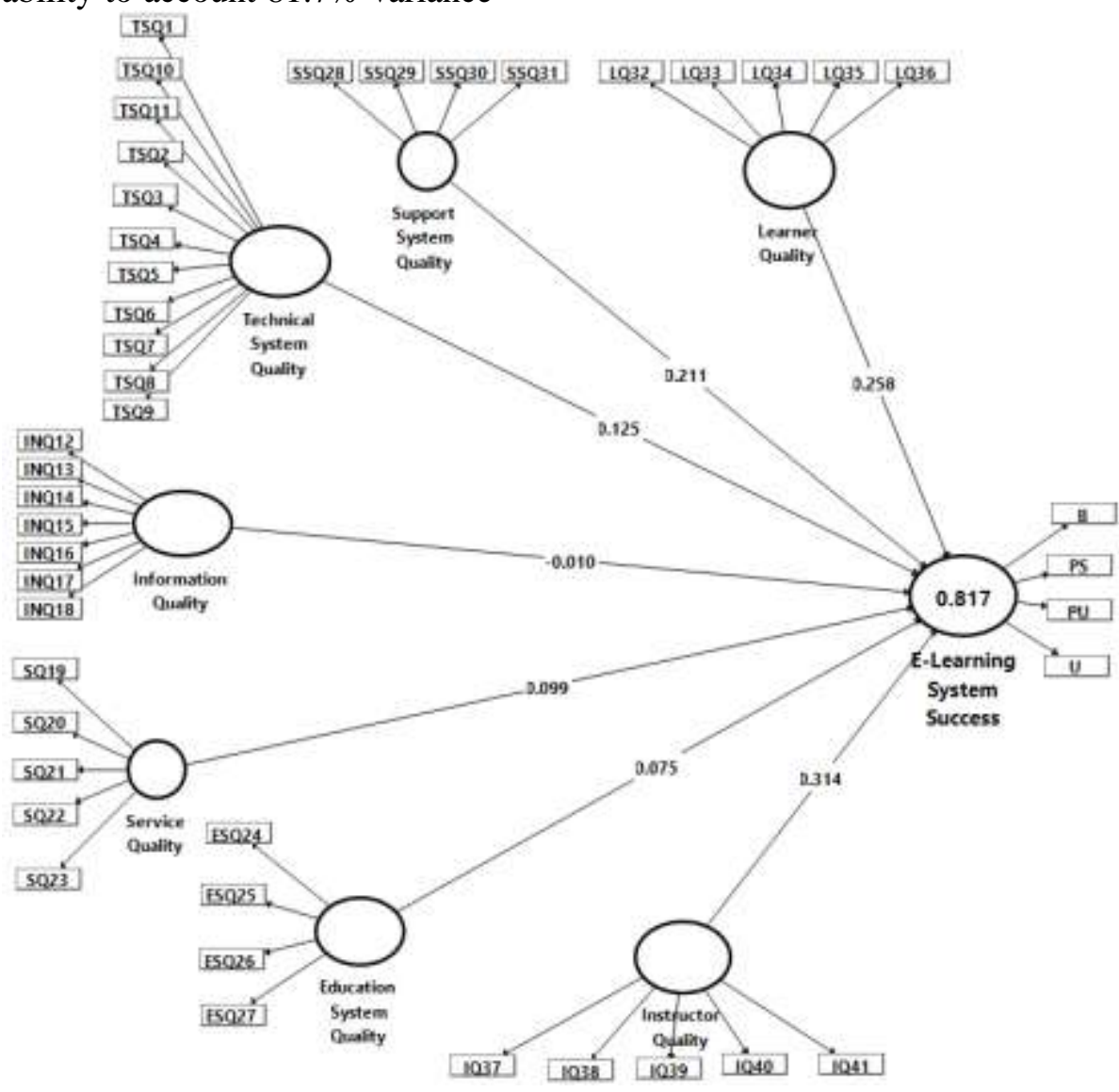

Figure 3 : Second-Order Structural Model

$\mathrm{n}=263$,

Survey Results (2020)

The effect size (f square) of PLS algorithm is the next measure of the structural model. The effect size is defined as "the increase in
$\mathrm{R}^{2}$ relative to the proportion of variance of the endogenous latent variable that remains unexplained" (Cohen, 1988, 
Henseler et al., 2009). As to Hair et al., (2017) and Cohen (1988), $0.35-\mathrm{f}^{2}$ value is regarded larger effect size, $0.15-\mathrm{f}^{2}$ value: medium effect size and $0.02 \mathrm{f}^{2}$ value equals to smaller effect size. Table 7 contains the effect size of corresponding latent constructs.

Table 7: Effect Sizes $\left(\mathbf{f}^{2}\right)$ of Structural Model

\begin{tabular}{|l|c|c|}
\hline & E-Learning System Success & Effect Size \\
\hline Education System Quality & 0.010 & No \\
\hline Information Quality & 0.000 & No \\
\hline Instructor Quality & 0.130 & Small \\
\hline Learner Quality & 0.088 & Small \\
\hline Service Quality & 0.021 & Small \\
\hline Support System Quality & 0.067 & Small \\
\hline Technical System Quality & 0.039 & Small \\
\hline
\end{tabular}

$\mathrm{n}=263$,

Survey Results (2020)

Based on the decision criterion, Education system Quality and Information Quality appear not having any effect while other independent variables possess small effect size on the variance of $\mathrm{R}^{2}$ (Cohen, 1988, Henseler et al., 2009). Finally, the structural model is assessed for its predictive relevance via the blindfolding (q Square). StoneGeisser Predictive relevance suggests that the $\mathrm{Q}^{2}$ value larger than $\left.\begin{array}{lll}0 & (0 & <\end{array}\right)$ indicates that exogenous constructs have predictive relevance over endogenous construct (Stone, 1974; Geisser, 1975; Hair, et al., 2017). The blindfolding of Construct Cross validated Redundancy results $0.579 \quad \mathrm{Q}^{2}$ value which is well above the threshold value of 0 . It implies that the E-learning system qualities have predictive relevance over E-Learning System Success. 


\section{DISCUSSION}

PLS-SEM results confirms $81.7 \%$ explanatory power of the predictor variables in explaining the variance of E-Learning Success. Further, Instructor Quality (0.314), Learner Quality (0.258), Support System Quality (0.211), Technical System Quality (0.125), and Service Quality (0.099), found significant in predicting the variance of ELearning System Success. Yet, the tested data does not prove that the Educational Systems Quality and Information Quality can predict the E-Learning Success. Findings are partly consistent with the findings of Al-Fraihat et al. (2020), Mosakhani \& Jamporazmey (2010), and AlFraihat et al. (2018) despite some anomalies are noted with respect to insignificant predictors namely; Educational Systems Quality (Kim, Trimi, Park, and Rhee, 2012; Mohammadi, 2015; Xing, Kim, and Goggins, 2015) and Information Quality (Klobas \& McGill, 2010; Eom et al., 2012; Chen, 2010; Lwoga, 2014). E-learning system here has viewed as a triangular conception in which teacher (i.e. facilitator) and the learner interact with each other via a technical platform: the system. All the significant predictors to e-learning success found closely attached to either of these three pillars of an elearning system. Hence, their power in affecting the success of e-learning system can be ramified. For instance, two leading predictors, Instructor Quality and Learner Quality directly associated with two of three pillars. They represent the live components of E-learning systems who are the contributors and as well the beneficiaries of Elearning systems. Thus, it is inveterate that the instructors and leaners to a greater extent should be responsible for success of the e-learning systems to which they are connected. Additionally, the rest of the significant predictors; Support System Quality, Technical System Quality, and Service Quality are elements of the other pillar; the technical platform. Hence, the results proved that the success of elearning system in a way is a communal contribution of all three parties to the system. On contrary, the insignificant factors appear loosely connected with either of the three main components of the e-learning system. Thus, the findings are believed to be revealing the factuality of the presumed relationships. The implications flag that the organizations need to emphasize on creating learning opportunities, knowledge sharing, and tapping knowledge at both individual \& corporate levels developing an e-learning culture in the process. Additionally, the study spotlighted the fact that even though global delivery of elearning is highly talked about, the real potential of e-learning depends on the local environment 
to a large extent (Ali, 2008). Elearning undoubtedly is a source of competitive advantage (Choudhury \& Pattnaik,2020). However, as pointed out in the paper, partners to the learning experience need to observe the changing dynamics of the learning environment and should follow an agile approach that enable adoption and diffusion of e-learning tools on a continuous basis.

\section{CONCLUSION}

Students today are exposing to different learning environments to gain the maximum value in learning experiences. Natural and man-made disasters such as COVID 19 pandemic, often threaten the continuation of physical learning experiences. This, together with many other socio economical drivers, have thrived the demand for elearning. Every institution is unique and has its own strengths in conducting online courses. The essence of quality education, in any form, is to ensure that learning objectives are achieved efficiently and effectively, without sacrificing the standards of the educator and institution. Although recent attention has increased e-learning evaluation, the current research base for evaluating e-learning is inadequate. Given the significance of the investments in implementing e-learning programs, the assessment of their success / effectiveness can't be misjudged (American Society for Training and Development, 2001). In that light, the present study contributes to the existing body of knowledge of e-learning systems by proposing a new model of assessing the e-learning systems success. Findings confirms that the proposed model holds superficial capacity to predict the variances in e-learning system's success. The previous studies (Al-Fraihat, et. al., 2020) offer confirmation of the theoretical implications of the EESS model in the context of developing countries. Study supports the practical implication of ensuring not only the technical systems quality but also the instructor, learner, service, support system, and technical system in any attempt to enhance the success of e-learning systems (Abbasi et.al, 2020: Aboagye et.al, 2021: Ali et.al., 2018: Mtebe and Raphael, 2018). Future studies are invited in different research sites (e.g. state and private universities) with different methodological imperatives. 


\section{REFERENCES}

Abbasi, S., Ayoob, T., Malik, A., \& Memon, S. I., 2020. Perceptions of students regarding E-learning during Covid-19 at a private medical college. Pakistan Journal of Medical Sciences, 36 (COVID19S4), S57.

Abdel-Wahab, A. G., 2008. Modeling Students' Intention to Adopt E-learning: A Case from Egypt. The Electronic Journal of Information Systems in Developing Countries, 34(1), 1-13.

Aboagye, E., Yawson, J. A., \& Appiah, K. N., 2021. COVID-19 and E-learning: The challenges of students in tertiary institutions. Social Education Research, 1-8.

Alavi, M. and Leidner, D.E., 2001. Research commentary: Technologymediated learning - A call for greater depth and breadth of research. Information systems research, 12(1), pp.1-10.

Al-Emran, M. and Shaalan, K., 2015, August. Learners and educators' attitudes towards mobile learning in higher education: State of the art. In 2015 International Conference on Advances in Computing,
Communications and Informatics (ICACCI) (pp. 907-913). IEEE.

Al-Emran, M., Salloum, S.A., Monem, A.A. and Shaalan, K., 2017. A survey of text mining in social media: facebook and twitter perspectives. $A d v$. Sci. Technol. Eng. Syst. J, 2(1), pp.127-133.

Al-Fraihat, D., Joy, M. and Sinclair, J., 2018. A comprehensive model for evaluating e-learning systems success. Distance Learning for Educators, Trainers and Leaders, 15(3), pp.57-74.

Al-Fraihat, D., Joy, M. and Sinclair, J., 2020. Evaluating E-learning systems success: An empirical study. Computers in Human Behavior, 102, pp.67-86.

Ali, A., \& Ahmad, I., 2011. Key factors for determining student satisfaction in distance learning courses: A study of Allama Iqbal Open University. Contemporary Educational Technology, 2(2), 118-134.

Ali, G.E. and Magalhaes, R., 2008. Barriers to implementing e-learning: a Kuwaiti case study. International journal of training and development, 12(1), pp.36-53. 
Ali, M., Raza, S. A., Qazi, W., \& Puah, C. H., 2018. Assessing e-learning system in higher education institutes. Interactive Technology and Smart Education.

Alireza, H., Fatemeh, K. and Shában, E., 2012. A model for measuring e-learning systems success in universities. Expert Systems with Applications.

Almaiah, M. A., AlKhasawneh, A., \& Althunibat, A., 2020. Exploring the critical challenges and factors influencing the E-learning system usage during COVID-19 pandemic. Education and Information Technologies, 25, 52615280.

Almaiah, M.A. and Man, M., $2016 . \quad$ Empirical investigation to explore factors that achieve high quality of mobile learning system based on students' perspectives. Engineering science and technology, an international journal, 19(3), pp.1314-1320.

Almaiah, M.A., Jalil, M.A. and Man, M., 2016. Extending the TAM to examine the effects of quality features on mobile learning acceptance. Journal of Computers in Education, 3(4), pp.453-485.
Al-Maroof, S., 2021. The Continuous Intention to Use E-Learning, from Two Different Perspectives. Education Sciences, 11, 6.

Al-Samarraie, H., Teng, B. K., Alzahrani, A. I., \& Alalwan, N., 2018. Elearning continuance satisfaction in higher education: a unified perspective from instructors and students. Studies in higher education, 43(11), pp. 2003-2019.

Bagozzi, R.P., Yi, Y. and Nassen, K.D., 1998. Representation of measurement error in marketing variables: Review of approaches and extension to three-facet designs. Journal of Econometrics, $89(1-2)$, pp.393-421.

Balaban, I., Mu, E. and Divjak, B., 2013. Development of an electronic Portfolio system success model: An information systems approach. Computers \& Education, 60(1), pp.396411.

Behera, S.K., 2013. E-and MLearning: A comparative study. International Journal on New Trends in Education and Their Implications, 4(3), pp.6578. 
Bell, B. S., \& Kozlowski, S. W., 2002. Adaptive guidance: Enhancing self-regulation, knowledge, and performance in technology-based training. Personnel Psychology, 55(2), 267-306.

Bhat, S., Raju, R., Bikramjit, A., \& D'Souza, R., 2018. Leveraging E-learning through Google classroom: A usability study. Journal of Engineering Education Transformations, 31(3), 129-135.

Bhuasiri, W., Xaymoungkhoun, O., Zo, H., Rho, J. J., \& Ciganek, A. P., 2012. Critical success factors for e-learning in developing countries: A comparative analysis between ICT experts and faculty. Computers \& Education, 58(2), 843-855.

Brinkerhoff, J., 2006. Effects of a long-duration, professional development academy on technology skills, computer selfefficacy, and technology integration beliefs and practices. Journal of research on technology in education, 39(1), 22-43.

Brown, R. E., 2001. The process of communitybuilding in distance learning classes. Journal of asynchronous learning networks, 5(2), 18-35.
Brown, T. H., 2003. The role of $\mathrm{m}$-learning in the future of e-learning in Africa. In $21 s t$ ICDE World Conference, 110, pp. 122-137.

Byrne, B. M., 2016. Structural equation modeling with AMOS: Basic concepts, applications, and programming (multivariate applications). New York : Routledge.

Cantoni, V., Cellario, M. and Porta, M., 2004. Perspectives and challenges in e-learning: towards natural interaction paradigms. Journal of Visual Languages \& Computing, 15(5), pp.333345.

Chen, C.W.D. and Cheng, C.Y.J., 2009. Understanding consumer intention in online shopping: a respecification and validation of the DeLone and McLean model. Behaviour \& Information Technology, 28(4), pp.335-345.

Chen, H.J., 2010. Linking employees'e-learning system use to their overall job outcomes: An empirical study based on the IS success model. Computers \& Education, 55(4), pp.1628-1639.

Chen, H.J., 2010. Linking employees'e-learning 
system use to their overall job outcomes: An empirical study based on the IS success model. Computers \& Education, 55(4), pp.1628-1639.

Cheng, Y. M., 2011. Antecedents and consequences of e-learning acceptance. Information Systems Journal, 21(3), 269-299.

Child, S., Blenkinsopp. E., Hall, A. and Walton, G., 2005. Effective E-learning for health professionals and students-barriers and their stations. A systematic review of the literaturefindings from the heXL project. Health Info. Lib. J. Dec. 22(2): 20-32

Chin, W.W., 2001. PLS-Graph user's guide. CT Bauer College of Business, University of Houston, USA, 15, pp.1-16.

Chopra, G., Madan, P., Jaisingh, P., \& Bhaskar, P. (2019). Effectiveness of elearning portal from students' perspective. Interactive Technology and Smart Education.

Choudhury, S., \& Pattnaik, S., 2020. Emerging themes in e-learning: a review from the stakeholders' perspective. Computers \& Education, 144, 103657.
Cidral, W.A., Oliveira, T., Di Felice, M. and Aparicio, M., 2018. E-learning success determinants: Brazilian empirical study. Computers \& Education, 122, pp.273-290.

Cohen, J. (1988). Statistical power analysisfor the behavioral sciences(2nd ed.).Hillsdale, $\quad \mathrm{NJ}$ : Erlbaum.

Cruz-Jesus, F., Vicente, M. R., Bacao, F., \& Oliveira, T., 2016. The educationrelated digital divide: An analysis for the EU-28. Computers in Human Behavior, 56, 72-82.

DeL one, W. H., \& McLean, E. R. (2003). The DeLone and McLean model of information systems success: Aten-year update. Journal of Management Information Systems, 19(4), 9 30.https://doi.org/10.1080/ 07421222.2003 .11045748

Ebner, M., Schön, S., Braun, C., Ebner, M., Grigoriadis, Y., Haas, M., ... \& Taraghi, B. (2020). COVID-19 epidemic as E-learning boost? Chronological development and effects at an Austrian university against the background of the concept of "E-Learning Readiness". Future Internet, 12(6), 94. 
Eom, S. B., \& Ashill, N. J., 2018. A system's view of e-learning success model. Decision Sciences Journal of Innovative Education, 16(1), 42-76.

Eom, S., Ashill, N.J., Arbaugh, J.B. and Stapleton, J.L., 2012. The role of information technology in e-learning systems success. Human Systems Management, 31(3-4), pp.147-163.

Eom, S., Ashill, N.J., Arbaugh, J.B. and Stapleton, J.L., 2012. The role of information technology in e-learning systems success. Human Systems Management, 31(3-4), pp.147-163.

Fathema, N., Shannon, D., \& Ross, M., 2015. Expanding the technology acceptance model (TAM) to examine faculty use of learning management systems (LMSs) in higher education institutions. MERLOT Journal of Online Learning \& Teaching, 11(2), 210232. Retrieved from http://jolt.merlot.org/Vol11 no2/Fathema 0615.pdf

Fernando, E., Murad, D. F., Warnars, H. L. H. S., \& Oktriono, K. (2019, November). Development Conceptual Model and Validation Instrument for E-Learning Succes Model at Universities in Indonesia: Perspectives influence of Instructor's Activities and Motivation. In 2019 International Congress on Applied Information Technology (AIT) (pp. 1-6). IEEE.

Fornell, C. and Larcker, D.F., 1981. Structural equation models with unobservable variables and measurement error: Algebra and statistics.

Fornell, C. and Larcker, D.F., 1981. Structural equation models with unobservable variables and measurement error: Algebra and statistics.

Freeze, R.D., Alshare, K.A., Lane, P.L. and Wen, H.J., 2010. IS success model in e-learning context based on students' perceptions. Journal of Information systems education, 21(2), pp.173-184.

Garcia-Smith, D. and Effken, J.A., 2013. Development and initial evaluation of the clinical information systems success model (CISSM). International Journal of Medical Informatics, 82(6), pp.539552.

Geisser, S., 1975. The predictive sample reuse method with applications. Journal of the American 
statistical Association, 70(350), pp.320-328.

Goodhue, D.L., Lewis, W. and Thompson, R., 2012. Does PLS have advantages for small sample size or nonnormal data? MIS quarterly, pp.981-1001.

Govindasamy, T 2002. Successful implementation of e-learning: pedagogical considerations. Internet and Higher Education 4:287299

Grönlund, Å., \& Islam, Y. M., 2010. A mobile e-learning environment for developing countries: The Bangladesh virtual interactive classroom. Information Technology for Development, 16(4), 244259.

Gulati, S., 2008. Technologyenhanced learning in developing nations: A review. The International Review of Research in Open and Distributed Learning, 9(1).

Gupta, S. and Bostrom, R.P., 2005. A research framework for collaborative eLearning in an end user training context. AMCIS 2005 Proceedings, p.256.

Hagos, Y., Garfield, M. and Anteneh, S., 2016, June. Measurement factors model for e-learning systems success. In 2016 IEEE Tenth International Conference on Research Challenges in Information Science (RCIS) (pp. 1-6). IEEE.

Hagos, Y., Garfield, M. and Anteneh, S., 2016, June. Measurement factors model for e-learning systems success. In 2016 IEEE Tenth International Conference on Research Challenges in Information Science (RCIS) (pp. 1-6). IEEE.

Hair, J.F., Ringle, C.M. and Sarstedt, M., 2011. PLSSEM: Indeed a silver bullet. Journal of Marketing theory and Practice, 19(2), pp.139152.

Halawi, L.A., McCarthy, R.V. and Aronson, J.E., 2008. An empirical investigation of knowledge management systems' success. Journal of computer information systems, 48(2), pp.121-135.

Hassanzadeh, A., Kanaani, F. and Elahi, S., 2012. A model for measuring elearning systems success in universities. Expert systems with Applications, 39(12), pp.10959-10966.

Hubalovsky, S., Hubalovska, M., \& Musilek, M. (2019). Assessment of the 
influence of adaptive Elearning on learning effectiveness of primary school pupils. Computers in Human Behavior, 92, 691-705.

Hussein, R., Aditiawarman, U., \& Mohamed, N., 2007. Elearning acceptance in a developing country: a case of the Indonesian Open University. In German eScience conference.

Iivari, J., 2005. An empirical test of the DeLone-McLean model of information system success. ACM SIGMIS Database: the DATABASE for Advances in Information Systems, 36(2), pp.8-27.

Islam, A. N., 2013. Investigating e-learning system usage outcomes in the university context. Computers \& Education, 69, 387-399.

Janelli, M. (2018). E-learning in theory, practice, and research. Bonpocbl образования, (4 (eng)).

Khan, B.H. ed., 2005. Managing e-learning: Design, delivery, implementation, and evaluation. IGI Global.

Kim, H. J., Hong, A. J., \& Song, H. D. (2019). The roles of academic engagement and digital readiness in students' achievements in university e-learning environments. International Journal of Educational Technology in Higher Education, 16(1), 1-18.

Kim, K., Trimi, S., Park, H. and Rhee, S., 2012. The impact of CMS quality on the outcomes of e-learning systems in higher education: an empirical study. Decision Sciences Journal of Innovative Education, 10(4), pp.575587.

Klobas, J.E. and McGill, T.J., 2010. The role of involvement in learning management system success. Journal of Computing in Higher Education, 22(2), pp.114134.

Klobas, J.E. and McGill, T.J., 2010. The role of involvement in learning management system success. Journal of Computing in Higher Education, 22(2), pp.114134.

Kruse, K., 2002. E-Learning and the Neglect of User Interface Design, ELearningGuru.com.

Lau, K. H., Lam, T., Kam, B. H., Nkhoma, M., Richardson, J., \& Thomas, S. (2018). The role of 
textbook learning resources in e-learning: A taxonomic study. Computers \& Education, 118, 10-24.

Lee, B. C., Yoon, J. O., \& Lee, I., 2009. Learners' acceptance of e-learning in South Korea: Theories and results. Computers \& education, 53(4), 13201329.

Lee, J. K., \& Lee, W. K., 2008. The relationship of $\mathrm{e}$ Learner's self-regulatory efficacy and perception of e-Learning environmental quality. Computers in human Behavior, 24(1), 3247.

Lee, M. C., 2010. Explaining and predicting users' continuance intention toward e-learning: An extension of the expectation-confirmation model. Computers \& Education, 54(2), 506-516.

Lee, Y.H., Hsieh, Y.C. and Hsu, C.N., 2011. Adding innovation diffusion theory to the technology acceptance model: Supporting employees' intentions to use e-learning systems. Journal of Educational Technology \& Society, 14(4), pp.124-137.

Liaw, S. S., Huang, H. M., \& Chen, G. D., 2007. Surveying instructor and learner attitudes toward e- learning. Computers \& Education, 49(4), 10661080.

Liaw, S.S. and Huang, H.M., 2013. Perceived satisfaction, perceived usefulness and interactive learning environments as predictors to self-regulation in e-learning environments. Computers \& Education, 60(1), pp.14-24.

Liu, S.H., Liao, H.L. and Peng, C.J., 2005. Applying the technology acceptance model and flow theory to online e-learning users' acceptance behavior. Elearning, 4(H6), p.H8.

Liu, S.H., Liao, H.L. and Peng, C.J., 2005. Applying the technology acceptance model and flow theory to online e-learning users' acceptance behavior. $E$ learning, 4(H6), p.H8.

Liu, Y., \& Wang, H., 2009. A comparative study on e-learning technologies and products: from the East to the West. Systems Research and Behavioral Science: The Official Journal of the International Federation for Systems Research, 26(2), 191-209.

Lwoga, E., 2014. Critical success factors for adoption of web-based learning management systems in Tanzania. International 
Journal of Education and Development using ICT, $10(1)$.

Lwoga, E., 2014. Critical success factors for adoption of web-based learning management systems in Tanzania. International Journal of Education and Development using ICT, $10(1)$.

Lwoga, E., 2014. Critical success factors for adoption of web-based learning management systems in Tanzania. International Journal of Education and Development using ICT, 10(1).

Maldonado, U. P. T., Khan, G. F., Moon, J., \& Rho, J. J., 2011. E-learning motivation and educational portal acceptance in developing countries. Online Information Review.

Marjanovic, U., Delić, M. and Lalic, B., 2016. Developing a model to assess the success of e-learning systems: evidence from a manufacturing company in transitional economy. Information Systems and eBusiness Management, 14(2), pp.253-272.

McGill, T.J. and Klobas, J.E., 2009. A task-technology fit view of learning management system impact. Computers \&
Education, 52(2), pp.496508.

Mohammadi, H., 2015. Investigating users' perspectives on e-learning: An integration of TAM and IS success model. Computers in human behavior, 45, 359-374.

Mohammadi, H., 2015. Investigating users' perspectives on e-learning: An integration of TAM and IS success model. Computers in human behavior, 45, 359-374.

Mohammadi, H., 2015. Investigating users' perspectives on e-learning: An integration of TAM and IS success model. Computers in human behavior, 45, pp.359-374.

Mosakhani, M. and Jamporazmey, M., 2010, September. Introduce critical success factors (CSFs) of elearning for evaluating e-learning implementation success. In $2010 \quad$ International Conference on Educational and Information Technology (Vol. 1, pp. V1-224). IEEE.

Mtebe, J. S., \& Raphael, C., 2018. Key factors in learners' satisfaction with the e-learning system at the University of Dar es Salaam, Tanzania. 
Australasian Journal of Educational Technology, 34(4).

Mtebe, J.S. and Raphael, C., 2018. Key factors in learners' satisfaction with the e-learning system at the University of Dar es Salaam, Tanzania. Australasian Journal of Educational Technology, 34(4).

Navimipour, N.J. and Zareie, B., 2015. A model for assessing the impact of elearning systems on employees' satisfaction. Computers in Human Behavior, 53, pp.475-485.

Ngai, E.W., Poon, J.K.L. and Chan, Y.H., 2007. Empirical examination of the adoption of WebCT using TAM. Computers \& education, 48(2), pp.250267.

Nguyen, T.D., Nguyen, T.M., Pham, Q.T. and Misra, S., 2014, June. Acceptance and use of e-learning based on cloud computing: the role of consumer innovativeness. In International Conference on Computational Science and Its Applications (pp. 159-174). Springer, Cham.

Nikolić, V., Petković, D., Denić, N., Milovančević, M., \& Gavrilović, S. (2019). Appraisal and review of e-learning and ICT systems in teaching process. Physica A: Statistical Mechanics and its Applications, 513, 456464.

Ong, C.S., Lai, J.Y. and Wang, Y.S., 2004. Factors affecting engineers' acceptance of asynchronous e-learning systems in high-tech companies. Information \& management, 4l(6), pp.795-804.

Ozkan, S. and Koseler, R., 2009. Multi-dimensional students' evaluation of elearning systems in the higher education context: An empirical investigation. Computers \& Education, 53(4), pp.1285-1296.

Ozkan, S. and Koseler, R., 2009. Multi-dimensional students' evaluation of elearning systems in the higher education context: An empirical investigation. Computers \& Education, 53(4), pp.1285-1296.

Ozkan, S., \& Koseler, R., 2009. Multi-dimensional students' evaluation of elearning systems in the higher education context: An empirical investigation. Computers \& Education, 53(4), 1285-1296.

Ozkan, S., \& Koseler, R., 2009. Multi-dimensional 
students' evaluation of elearning systems in the higher education context: An empirical investigation. Computers \& Education, 53(4), 1285-1296.

Park, S. Y., 2009. An analysis of the technology acceptance model in understanding university students' behavioral intention to use e-learning. Journal of Educational Technology \& Society, 12(3), 150-162.

Park, S.Y., 2009. An analysis of the technology acceptance model in understanding university students' behavioral intention to use e-learning. Journal of Educational Technology \& Society, 12(3), pp.150-162.

Peng, D.X. and Lai, F., 2012. Using partial least squares in operations management research: A practical guideline and summary of past research. Journal of Operations Management, 30(6), pp.467-480.

Pham, L., Limbu, Y. B., Bui, T. K., Nguyen, H. T., \& Pham, H. T. (2019). Does e-learning service quality influence e-learning student satisfaction and loyalty? Evidence from Vietnam. International Journal of Educational Technology in
Higher Education, 16(1), 1-26.

Po-An Hsieh, J.J. and Wang, W., 2007. Explaining employees' extended use of complex information systems.

Raab, R. T., Ellis, W. W., \& Abdon, B. R., 2002. Multisectoral partnerships in e-learning A potential force for improved human capitaldevelopment in the Asia Pacific.Internet and Higher Education, 4, $217-$ 229

Radha, R., Mahalakshmi, K., Kumar, V. S., \& Saravanakumar, A. R. (2020). E-Learning during lockdown of Covid-19 pandemic: A global perspective. International journal of control and automation, 13(4), 10881099.

Rajab, K. D. (2018). The effectiveness and potential of E-learning in war zones: An empirical comparison of face-to-face and online education in Saudi Arabia. IEEE Access, 6, 67836794.

Rakic, S., Tasic, N., Marjanovic, U., Softic, S., Lüftenegger, E., \& Turcin, I. (2020). Student Performance on an ELearning Platform: Mixed Method

Approach. 
International Journal of Emerging Technologies in Learning, 15(2).

Roca, J.C., Chiu, C.M. and Martínez, F.J., 2006. Understanding e-learning continuance intention: An extension of the Technology Acceptance Model. International Journal of humancomputer studies, 64(8), pp.683-696.

Ruiz, J. G., Mintzer, M. J., \& Leipzig, R. M., 2006. The impact of e-learning in medical education. Academic medicine, 81(3), 207-212.

Ruiz, J. G., Mintzer, M. J., \& Leipzig, R. M., 2006. The impact of e-learning in medical education. Academic medicine, 81(3), 207-212.

Salloum, S. A., Al-Emran, M., Habes, M., Alghizzawi, M., Ghani, M. A., \& Shaalan, K. (2019, October). Understanding the impact of social media practices on e-learning systems acceptance. In International Conference on Advanced Intelligent Systems and Informatics (pp. 360-369). Springer, Cham.

Sander, T., 2020. 100 Essential E-Learning Statistics for 2021,E-Learning.org
Santhanam, R., Sasidharan, S. and Webster, J., 2008. Using self-regulatory learning to enhance elearning-based information technology training. Information Systems Research, 19(1), pp.26-47.

Sarstedt, M., Ringle, C.M., Henseler, J. and Hair, J.F., 2014. On the emancipation of PLS-SEM: A commentary on Rigdon (2012). Long range planning, 47(3), pp.154160.

Selim, H. M., 2003. An empirical investigation of student acceptance of coursewebsites.Computers \& Education, 40(4), 343360 .

Shahmoradi, L., Changizi, V., Mehraeen, E., Bashiri, A., Jannat, B., \& Hosseini, M. (2018). The challenges of E-learning system: Higher educational institutions perspective. Journal of education and health promotion, 7.

Shraim, K. and Khlaif, Z., 2010. An e-learning approach to secondary education in Pal-estine: opportunities and challenges. Information Technology for Development, Vol. 16, No. 3,pp. 159-173. So, T. and Swatman, P. (2006). eLearning Readiness of 
Hong Kong Teachers, [online],

Available:http://www.insyl. unisa.edu.au/publications/w orking-papers/2006-05.pdf

Song, D., Lin, H. and Yang, Z., 2007, September. Opinion mining in e-learning system. In 2007 IFIP international conference on network and parallel computing workshops (NPC 2007) (pp. 788-792). IEEE.

Stalling, D. (2002). Measuring Success in the Virtual University. The Journal of Academic Librarianship, 28(1). 47-53

Stone, M., $\quad 1974$ Cross-validatory choice and assessment of statistical predictions. Journal of the Royal Statistical Society: Series B (Methodological), 36(2), pp.111-133.

Sun, P.C., Tsai, R.J., Finger, G., Chen, Y.Y. and Yeh, D., 2008. What drives a successful e-Learning? An empirical investigation of the critical factors influencing learner satisfaction. Computers \& education, 50(4), pp.11831202.

Sun, P.C., Tsai, R.J., Finger, G., Chen, Y.Y. and Yeh, D., 2008. What drives a successful e-Learning? An empirical investigation of the critical factors influencing learner satisfaction. Computers \& education, 50(4), pp.11831202.

Tarhini, A., Hone, K. and Liu, X., 2013. User acceptance towards web-based learning systems: Investigating the role of social, organizational and individual factors in European higher education. Procedia Computer Science, 17, pp.189-197.

Teo, T. S., Kim, S. L., \& Jiang, L. (2020). E-learning implementation in south Korea: Integrating Effectiveness and Legitimacy Perspectives. Information Systems Frontiers, 22(2), 511-528.

Thiyagarajan, C., \& Suguanthi, G. M. (2021). Effectiveness in online teaching from students perspective using empirical analysis. Materials Today: Proceedings.

Tularam, G. A. (2018). Traditional vs Nontraditional Teaching and Learning Strategies-the case of E-learning!. International Journal for Mathematics Teaching and Learning, 19(1), 129-158.

Valencia-Arias, A., ChalelaNaffah, S., \& Bermúdez- 
Hernández，J. (2019). A proposed model of elearning tools acceptance among university students in developing countries. Education and Information Technologies, 24(2), 10571071.

Voorhees, C.M., Brady, M.K., Calantone, R. and Ramirez, E., 2016. Discriminant validity testing in marketing: an analysis, causes for concern, and proposed remedies. Journal of the academy of marketing science, 44(1), pp.119-134.

Wang, H., Xu, H., Chan, H. C., \& Chen, L., 2002. Critical success factors for webbased organizational IT training systems. In International Conference on Web-Based Learning (pp. 142-153). Springer, Berlin, Heidelberg.

Wang, Y. S., 2003. Assessment of learner satisfaction with asynchronous electronic learning systems. Information \& Management, 41(1), 75-86.

Wang, Y.S. and Liao, Y.W., 2008. Assessing eGovernment systems success: A validation of the DeLone and McLean model of information systems success. Government information quarterly, 25(4), pp.717733.

Welsh, E. T., Wanberg, C. R., Brown, K. G., \& Simmering, M. J., 2003. E-learning: emerging uses, empirical results and future directions. international Journal of Training and Development, 7(4), 245258.

Wong, K.K.K., 2013. Partial least squares structural equation modeling

(PLS-SEM) techniques using SmartPLS. Marketing Bulletin, 24(1), pp.1-32.

Xing, W., Kim, S.M. and Goggins, S., 2015. Modeling performance in asynchronous CSCL: an exploration of social ability, collective efficacy and social interaction. International Society of the Learning Sciences, Inc. [ISLS].

Zhang, D., \& Nunamaker, J. F., 2003. Powering e-learning in the new millennium: an overview of e-learning and enabling technology. Information systems frontiers, 5(2), 207218.

Zhang, D., 2005. Interactive multimedia-based e-learning: A study of effectiveness. The American Journal of Distance Education, 19(3), 149-162. 
Tennakoon W.D.N.S.M., \& Lasanthika W.A.J.A.J.M., Wayamba Journal of Management 12 (1)

Zhang, D., Zhao, J. L., Zhou, L., \& Nunamaker Jr, J. F., 2004.

Can e-learning replace classroom learning?

Communications of the ACM, 47(5), 75-79. 